\title{
Corporate Fraud: Causes, Effects, and Deterrence on Financial Institutions in Ghana
}

\author{
Osei-Assibey Mandella Bonsu \\ Li Kao Dui \\ Zou Muyun \\ Evans Kwabena Asare \\ Isaac Adu Amankwaa
}

School of Finance and Economics, Jiangsu university, Zhenjiang, P.R China

Doi:10.19044/esj.2018.v14n28p315 URL:http://dx.doi.org/10.19044/esj.2018.v14n28p315

\begin{abstract}
This paper focuses on finding the causes, effects, and deterrence and prevention of corporate fraud in the financial institution of Ghana. In particular, we examine the effects of fraud on a firm's financial performance. A cross sectional model was used to find the effects of financial institutions fraud on financial performance. It was revealed that fraud has a significant negative effects on financial performance i.e. Return on Assets of financial institutions in Ghana. However, structured questionnaires were also used to find out the perception of Accountants, Auditors, and management on the main causes of banking fraud and deterrence and prevention methods in curbing the menace. It was revealed that weaker internal control, inadequate training and fraud policies, failed documents, and proper remuneration are the strong arsenal that causes fraud in financial institutions of Ghana. Moreover, organizational use of password protection, good remuneration, employee's background checks, and adequate fraud training were perceived as the most deterrence and prevention method in fighting fraud in financial institutions. Our results have practical implication for management, accountants, auditors, and all stakeholders in financial institutions on the effects of fraud on firms financial performance and in mounting fool proof methods in curbing this canker and reducing it to its bearest minimum. The study contributes deterrence and prevention methods aimed at improving its effectiveness in reducing fraud in Ghana and West Africa.
\end{abstract}

Keywords: fraud, deterrence and prevention, Return on Assets, Financial institutions, Ghana 


\section{INTRODUCTION}

Corporate fraud plans go past the extent of a representative's expressed position, and are set apart by their unpredictability and monetary effect on the business, different workers and outside gatherings (Investopedia" n.d.). Corporate fraud is an unscrupulous exercises executed by an organization or workers of an organization in a way to give leeway to the executing organization or individual representatives of the organization. The concern of corporate fraud has increased recently, in which billions of monies have been wiped away and have led to grinding down of investors trust in financial markets. In fact, fraudulent acts have a terrific loss on a firm's value and the sectors of a country. According to the Association of Certified Fraud Examiners, 2004 estimates, about six percent of firm's revenue amounting $\$ 660$ billion per year are lost as a result of accounting fraud in the United States of America. The Association of Certified Fraud Examiners in their 2008 report to the U.S nations on fraud shown that U.S organizations alone lose 7 percent of their annual revenue to fraud amounting to US\$994 billion in losses. Globally, there has been 140 percent increase in the number of companies reporting financial misrepresentation, a 133 percent increase in the number reporting money laundering, and 71 percent increase in the number reporting corruption and bribery (Association of Certified Fraud Examiners, 2009). PricewaterhouseCoopers (2011) in their survey revealed that the victims of economic fraud in Malaysia incurred financial losses of between US $\$ 100,000$ to US $\$ 5,000,000$ during the particular year. The organization also experienced great collateral damage including damage to employee morale, brand, reputation, and business. Corporate fraud can lead to a closure of an organization. Numerous losses that corporate fraud has caused, in some cases, happened and were reported in Asia-pacific, the Americans, Africa, Russia and Middle East as well as in Europe.

Corporate fraud has emerged and has become a cankerworm that has eaten deep into Ghana economy, especially the financial sectors in which billions of Ghana cedi has been lost to fraudsters. KPMG Africa Barometer (2014) in their survey revealed that the value of all reported cases in Africa has increased from 10.8 billion dollars to 11 billion dollars. The fraudulent act knocked both public and private institutions especially in the financial institutions perpetrated by employees in collaboration with clients. The total monetary value involved in all reported fraud cases in corporate financial institutions, both attempted for the fiscal year 2016-2017, amounted to approximately GH $\$ 244.32 \mathrm{~m}$ according to the Central Bank of Ghana. Basically, fraud is a primary economic grievance for financial institutions and national economies (Zunzunegui, Belanger et al., 2017). Fraud and its management have been the main factor in the trouble of banks and, as much as possible, different measures have been taken to limit the rate of 
misrepresentation. Despite everything, it ascends constantly in light of the fact that fraudsters dependably gadget key ways of submitting extortion.

According to the Association of Certified Fraud Examiners, most fraudulent acts are perpetrated by employees in an organization. Despite the fact that this phenomenon is not unique to the financial institutions industry or exceptional to Ghana alone, the high occurrence of misrepresentation inside the banking industry has turned into an issue to which preventions must be given in perspective of the huge monies included and its unfriendly ramifications on the economy.. The effects of fraud reduced the assets of financial institutions and increase the liability of any company. Nevertheless, researchers have worked little on the quantum of the effects of fraud on the financial performance of financial institutions.

Most of the research topics have concentrated on the pervasiveness of fraud in financial markets in the advanced economics, but little in Ghana and Africa as well. However, literature shows that mostly qualitative approaches were adopted to look at this issue with few using a quantitative approach to analyze the problem at hand. This study discusses these research gaps in the financial institutions industries in the context of Ghana. The main purpose of the research is to measure the effects of fraud committed by employees or managers, customers, and accountants against financial institutions in Ghana. The study is based on accountants perceptive on financial institutional fraud against its financial performance. The supporting objectives are the following: (i) to find the causes of fraud in financial institutions and (ii) to determine the deterrence and prevention methods that will help curb fraud in financial institutions in Ghana.

The remaining part of this paper is organized as follows. Section two presents literature review concerning and addressing fraud. Section three highlights the research methodology. Section 4 reports the results of the main tests and the additional test. The final section draws the final conclusion.

\section{LITERATURE REVIEW Definition of Fraud}

A well-known meaning of fraud in literature was given by the Association of Certified Fraud Examiners (2016) "as using deception to make a personal gain for one's self dishonestly and create a loss for another." This may occur and might include activities such as theft, corruption, conspiracy, embezzlement, assets misappropriation, money laundering, bribery, and a position of trust or fiduciary relationship. $\mathrm{Xu}$, Zhang et al. (2017) defined fraud as any act in which individuals or a group of people were made to gain an undue advantage in an organization. The fraudulent act can be committed either by internal or external individuals in the organization by usually preparing fake financial statement to make individuals invest in the entity. 
Fraud is an act made to cheat on people and to reduce their confidence in financial institutions (Lang \& Wambach, 2013). Such scandals usually take the form of gaining finances, material, and even conceal payments in an

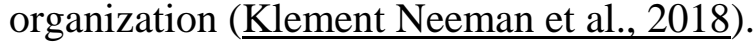

\section{Types of Fraud in Financial Institutions}

In most literature, financial institutions fraud has been grouped into six (6), namely: internal fraud, stolen checks, forgery, Fraudulent Loans, Forged Documents, Accounting Fraud, and Electronic fraud. However, in this research, banking or financial institution fraud is grouped into three, namely: internal fraud, accounting fraud, and external Fraud. The basis for this groupings stems from whether the banking fraud is committed within or outside a financial institution.

In addition, the basis for this classification stems from whether the insurance fraud is committed within or outside an insurance company.

\section{Internal Fraud}

In their study, Chen Zhu et al. (2011) argued that fraudulent acts made within most financial institutions comes in the form of internal fraud. This refers to fraud committed by employees and the fraud committed by the institutions itself. To make this statement valid, the said fraud types were committed by workers within the financial institutions.

\section{External Fraud}

External fraud can also emerge from external individuals or stakeholders who are directly related to the financial institution. This occurs in the form of stolen checks, fraudulent loans, forged documents and Electronic fraud. Stolen checks is a fraudulent practice that involves having access to one's mail such as a tax authority or corporate payroll. After stealing the checks, they open a bank account using an assumed name, and deposit in the checks. Fraudulent Loans occurs when an individual who requested for a loan, knowing that he or she will immediately file bankruptcy, has committed bank fraud. Forging occurs when a person alters a check by changing the name or some other information on the face. Altering the amount of the check, such as adding a zero to the end of a number, can turn a $\$ 20$ check into a $\$ 200$ check, putting more cash into the forger's pocket. Electronic fraud occurs when someone creates a website for the purpose of posing as a bank or a financial institution, to fraudulently obtain money deposited by a person (de Sá Pereira et al., 2018). 


\section{Accounting Fraud}

Accounting fraud is the intentional manipulation of banks financial statement to create a façade of organizations financial health. This act involves accountant or even the organizations and misleading shareholders and even investors. This happens when Accountants falsify its financial statement by overstating revenue or assets (Lisic Silveri et al., 2015).

\section{Fraud in the Ghanaian Financial Institutions}

The section below summarizes the overview of the Financial Institution in the economy of Ghana and the phenomenon of fraud in the industry's activities and data set.

\section{Overview of Ghanaian Financial Institutions Market}

One of the components of the Ghanaian financial services is the banking or the financial institutions. The Ghanaian financial institutions have experienced an exponential growth in recent years with the Central Bank of Ghana creating an enabling environment coupled with government pragmatic policies. The number of banking (financial) institutions keeps increasing after banking business were made to focus on lending, savings, and advisory roles (Banking Act, 673). Recently, there has been exponential and significant increase in growth and returns of financial institutions since most Ghanaians are accepting the essence of savings, treasury bills, and fixed deposits.

Currently, all existing thirty-two (32) financial institutions believed that the disequilibrium observed in the banking market of Ghana as a result of the total number of fraud-related issues have become prevalent in the financial institution market. The financial organizations have become more relevant which was shown by key indicators due to the comparison of the expansion of Ghanaian economy and the banking industry market (KPMG Ghana, 2014). Earned interests, liberation, and establishment of divestiture law by the government of Ghana (Law, 1993; PNDC law 326) are known and considered to be a well-grounded indicators of the expansion of the financial institutions in Ghana (Divestiture Implementation Committee Ghana, 2017). Therefore, this means that financial institutions are improving its relative position in the economy of Ghana with Ghana commercial bank, Ecobank Ghana Limited, ADB Bank Limited, and Barclays Bank; in addition, Access Bank was taking the lead roles in Ghanaian banking Sector (KPMG, 2014).

\section{Fraud in Financial Institutions of Ghanaian Market}

Fraud is immune and is regarded as one of the numerous enemies of the financial Institutions in Ghana (KPMG, Ghana). With this, accountants, auditors, management, government, and all stakeholders have come together mounting fool proof methods to reduce fraud and curb the financial institutions industry (LiBonsu et al., 2018). It is worthy to note that financial institutions 
have been characterized by the attitudes towards fraud. Meanwhile, financial institutions in the banking industry are willingly offering new and attractive products, increasing their market share and floating shares, and they have entered into the battle of lowering loan interest rate and encouraging and supporting entrepreneurs. It seems vivid that the behavior of the Ghanaian market has allowed the emergence of different kinds of fraud. This can be attributed to the complete lack of coordination among the financial institutions (PWC, 2103).

Consequently, there is no official institution controlling fraud or devoted to fraud detection in the Ghanaian banking industry, neither are there companies' implemented systems to control fraud than just inspections which are done by the institutions internal audit or accountants. Then again, from an external point of view, financial institutions are yet to be seen by consumers as associations which make extensive benefits in Ghana to the detriment of their consumers (Carl, 2017). In this way, it is fitting to cheat back up plans' and benefit from the protection contract. In 2007, PriceWaterhouseCoopers survey identified that approximately $71.4 \%$ of all fraud was committed by insiders or internal perpetrators. Albeit, bigger organizations will probably encounter monetary wrongdoing while, on the other hand, extortion might become more exorbitant for private ventures (Thomas \& Gibson, 2003; PriceWaterhouseCoopers (PWC), 2003). The normal independent venture misrepresentation added up to $\$ 98,000$ per event contrasted with $\$ 105,500$ per occurrence for substantial organizations (Association of Certified Fraud Examiners, 2004). For each worker premise, misfortunes from misrepresentation can be as much as 100 times more prominent for little firms than vast firms (Association of Certified Fraud Examiners, 2004; Wells, 2003).

\section{Causes of Fraud in Financial Institutions}

The fraud types in financial institutions and their causes which exist in the banking industry in Ghana are summarized as shown below:

(a) Poor Fraud Policy and Training: Employees would engage in fraud when fraud policies are not vividly set, as well as training for guiding employees.

(b) Poor Remuneration: Poor compensations and poor states of administration can likewise cause and empower misrepresentation. Representatives that are inadequately paid are frequently enticed to deceitfully change over a portion of the managers' monies to their own utilization so as to meet their own and social needs

(c) Inexperience Personnel: Inexperience staffs are helpless in conferring unexpected extortion by falling to the structure of various traps of fraudsters. Unpracticed work force are probably not going to see any 
extortion endeavors and take important prudent steps to checkmate the fraudster or get the identification procedure under way.

(d) Poor Book-Keeping: Powerlessness to keep up fitting books of records together with inability to accommodate the different records rely upon day by day, week after week or month to month premise as a general rule that can be pull into misrepresentation.

(e) Failure to Check Employee's Background: Organizations usually do not check and screen employees and it is the first line of defense against fraud. According to survey conducted by PriceWatersCoopers (2007), 71.4 percent of all fraud cases was committed by insiders in the organizations.

(f) Annual Auditing: Organizations are victimized by fraudulent acts as a result of failure of conducting annual audits.

\section{Theoretical Review \\ Fraud Triangle}

Fraud triangle is a theory developed in 1971 by Dr. Donald Cressey in his studies of criminology, specifically the behavior of fraudsters which describes the factors that propel them to commit fraud in an organization. According to Cressey in fraud triangle, for fraud to occur, three conditions must exist: rationalizations, pressures, and opportunity. When fraud triangle is instituted in the banking and financial sectors in Ghana, it gives a valuable framework to analyze individual act in the banking industry.

\section{OPPORTUNITY}

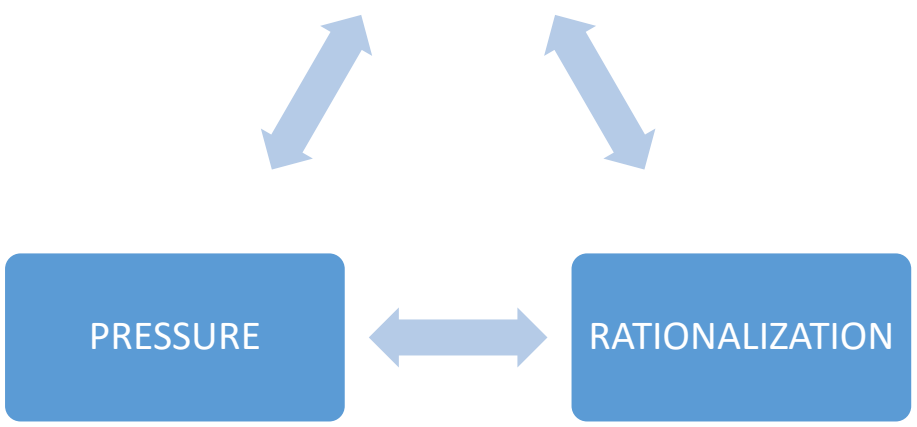

Figure 1. Dr. Cressey Fraud Triangle

Basically, pressure is what causes people to commit fraud in an organization. This pressure comes in the following forms: financial needs, work related pressures, and pressures as a way for material possession. It can 
also result due to one's inability to pay bills, medicals, addiction to drugs as well a desire for luxury things.

Therefore, what accounts for the rise of this incidence is opportunity. When opportunities are eliminated, then the incidence of fraud can be greatly reduced. An opportunity to commit fraud, to conceal it, and to avoid being punished is the critical factor that pushes individuals in committing fraud against most financial institutions. For opportunity to prevail in order for individuals to commit fraud stems from weaker internal control. The more internal controls an institution mounted and implemented, the less opportunity there should be for perpetrators or employees to commit fraud. Therefore, it is very imperative that internal controls should be effective and efficient so as to prevent future occurrence of fraud.

Rationalization is the last factor Cressey talked about on his development of fraud triangle. A normal component of keeping money extortion and all clerical wrongdoing occurs due to the absence of emotions or impassion communicated by guilty parties coming from a progression of reasons or defenses. Thus, this is with the aim of freeing themselves from the blame emerging from degenerated conduct.

Several researchers has commented and called for modifications of the fraud triangle to create either a fraud diamond (Wolfe \& Herman son, 2004 as cited by Akomea et al., 2016) or fraud pentagon (Marks, 2009). Wolfe argued that capability arising from ones position within an organization blend with intellectual and cognitive traits and abilities, allow potential offenders to recognize a fraud opportunity, and it helps them to turn it into a reality. Raval (2013) has recommended a detailed and thorough research of the rationalization condition of the fraud triangle by Cressey. He announced that banking fraud is a human act. As a result, he advocated a series of propositions in a predictive manner for future research.

\section{Game Theory}

Dixit and Nalebuff (1960) coined game theory and the emphasis of the theory was on games of pure conflict. As stated by Dixit, the essence of a game is the interdependence of player's strategies and decision making strategically. According to the theory, there are two distinct types of strategic interdependence, sequential and simultaneous. In the former, the players proceed in order with each being aware of the others' foregoing actions. In the latter, the players act at the same time with each being ignorant of the others' actions (Montet \& Serra, 2003).

The theory is imperative to this study since it is a formal study of decision- making where several players must make choices that potentially affect the interests of the other players. Maintaining fraud policy and training, annual auditing, good remuneration, employee's background checks, bank 
reconciliation, and good corporate governance in financial institution industry in Ghana are crucial constituent that requires strategies and decision making. The banking industry has gotten many players in which each outwits the other self-gain. Every financial institutions aspiration's aim is to gain profits for expansion, while that of the consumers is to receive value for the monies and services. If such is not met, consumers will use some unwonted ways to recover them. It was clearly demonstrated that finite games must always have equilibrium point, at which all players choose actions which are best for them given their opponents' choices (Dixit \& Nalebuff (1960) as cited 2005 by Gill et al.).

\section{Conceptual Framework}

The conceptualization of the study assumes a relationship between the financial institutions financial performance (embodied by Return on Assets (ROA)) and the effects of financial institution fraud, namely: increased operating cost, loss of money, low Asset quality, loss of public confidence, negative abnormal returns, and adverse effect on market share. They are captured in the figure below:

Number of Years in Operation

Effects of Fraud

Increased operational

Loss of Money

Low Asset Quality

Negative Image

Abnormal Returns

Adverse Effects of Markets

Total Long term capital
Types of Fraud

Internal Fraud

Stolen Checks

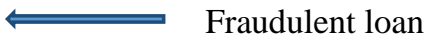
$(\mathrm{ROA})$

Forged Documents

Electronic Fraud

Accounting Fraud

Dependent Variable

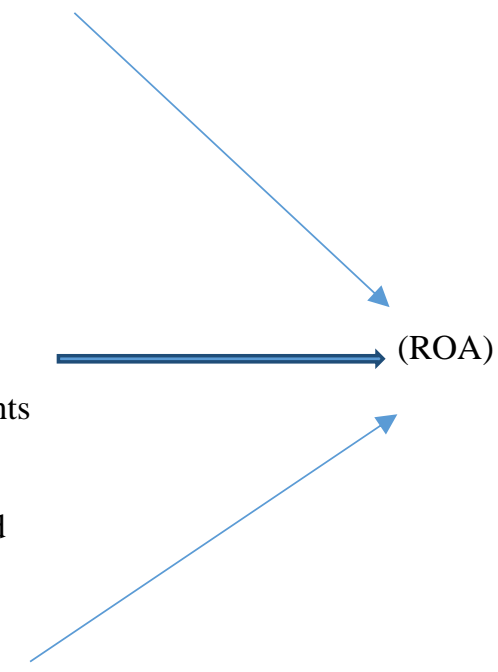

Independent Variables

\section{Empirical Review}

Jeffords et al. (1992) as cited by Schuchter and Levi (2015) "examined 910 cases during a 9 year period to assess the specific risk factors cited and, thus, approximately 64 percent of cases were classified under internal control risks." Likewise, Calderon and Green (1994) "did an investigation of 114 
actual corporate fraud causes from a period of 1986 to 1990 . It was revealed in the study that professional and managerial employees were involved in $45 \%$ of the cases." Ziegenfuss performed a study to determine the amount and the type of fraud occurring in the state and local government. Bhasin (2015) assessed the impacts of fraud on financial institutions performance in Nigeria during 2001- 2011 using Pearson correlation and multiple regression analysis (Bhasin, 2015). They suggested that banks in Nigeria should strengthen their internal control systems and the regulatory bodies ameliorate their supervisory role. Moreover, Khanna and Arora (2009) investigated the reasons for banks fraud and execution of preventive security controls in Indian financial institutions industry. The study seeks to scrutinize the various causes of financial institutions fraud. The finding indicates that lack of training, overburden staff, poor remuneration, and low compliance level are the main reasons individuals fraud financial institutions.

\section{RESEARCH METHODOLOGY Research Design}

The study employs descriptive and exploratory research designs. These research designs were utilized to collect and analyze data which has helped in establishing the relationships between the variables. The research also adopted quantitative research approach to offer description of fraud in financial institutions and its effect on companies in Ghana.

\section{Population and Sample Size}

The population of the study comprised of all financial institutions in Ghana. Ghanaian financial institutions are made of twenty five (25) commercial banks and twenty (20) rural banks (Central Bank of Ghana, 2015). The employees of these institutions are tellers, marketing managers, customer care, and relationship managers, accountants, auditors and others. In this study, accountants and auditors were randomly selected from each financial institution in Ghana as at 2015 to match the secondary data (financial statement) for the analysis.

\section{Data Gathering Instrument}

A survey questionnaires were used to collect primary data directly from the financial institutions, and the secondary data of annual financial statements of financial institutions were obtained from Ghana Stock Exchange as at 2013 to 2017. The questionnaires used in the study were tested before it was administered to ensure readability and effectiveness (Idolor, 2010). With this, professional Auditors and Accountants from different financial institutions evaluated the questionnaires for quality assurance of the significant measurement of the objectives of the study. Thus, irrelevant items were 
dismissed before it was administered. Cronbach Alpha helps in evaluating the reliability of questionnaires and, therefore, the questionnaires of this study helps to measure the internal consistency of the constructs. The reliability coefficient has to be 0.7 or more of the Cronbach's Alpha so that the reliability can be acceptable (Cooper \& Schindler, 2008).

Table 1

\begin{tabular}{|l|l|}
\hline Scale & Cronbach's Alpha \\
\hline Internal fraud & 0.812 \\
\hline Stolen checks & 0.725 \\
\hline Fraudulent loans & 0.825 \\
\hline Forged documents & 0.712 \\
\hline Electronic fraud & 0.817 \\
\hline Accounting fraud & 0.723 \\
\hline
\end{tabular}

As shown above, it is clear that all variables have coefficients $>0.7$. Thus, they befit in the data analysis. The financial performance (Return on Assets) and long term capital of the regression model were extracted from the annual financial statements of the ten (10) financial institutions listed on the Ghana stock Exchange as at 2013 to 2017. With this, the data serves as a secondary data for this paper.

\section{Method of Data Analysis}

The study used cross-sectional multiple regression model in the analysis of the effects of banking fraud on the financial performance of financial institutions in Ghana and is given by:

$$
\begin{gathered}
R O A_{1}=\alpha_{0}+\alpha_{1} I N T F_{1}+\alpha_{2} S_{T C S_{2}}+\alpha_{3} \text { FRLS }_{3}+\alpha_{4} \text { FDOC }_{4}+\alpha_{5} E L F D_{5}+\alpha_{6} \text { ACCFD }_{6} \\
+\alpha_{7} L G T_{7}+\alpha_{8} N Y_{9}+\varepsilon_{i}
\end{gathered}
$$

ROA $=$ Return on Assets as at 2013 to 2017 of the financial institution

INTF $=$ Internal Fraud as at 2013 to 2017 of the financial institution

STCS $=$ Stolen Checks as at 2013 to 2017 of the financial institutions

FRLS $=$ Fraudulent Loans as at 2013 to 2017 of the financial institution

FDOC $=$ Forged Documents as at 2013 to 2017 of the financial institution

ELFD $=$ Electronic Fraud as at 2013 to 2017 of the financial institution

ACCFD $=$ Accounting Fraud as at 2013 to 2017 of the financial institutions

LGT $=$ Long Term investment of the institutions

NY $=$ Number of Years of the operation of the institutions as at the 2017 $\varepsilon_{i}=$ Error term.

The dependent variable of the study is the ROA which is given by $\mathrm{ROA}=\frac{\text { NETINCOME }}{\text { TOTAL ASSETS }}$

Furthermore, net income can be found on the Income statement. It can also be profit after tax on profit and loss account. Total Assets is made up of non-current assets and current assets. The key independent variables in this 
study are embodied by the types of fraud associated with financial institutions: Internal Fraud, Stolen Checks, Fraudulent Loans, Forged Documents, and Electronic Fraud and Accounting Fraud. They are represented by the effects they pose on the firm's financial performance. This effects stem from fraud indicators in financial institutions fraud literature (Purnamasari \& Amaliah, 2015).

Respondents were asked about the effects of fraud in financial institutions on their financial performance using Likert scale ranges from (1) strongly disagree to strongly agree (7). The results from the respondents on the effects of the types of fraud (internal fraud, stolen checks, forged documents, fraudulent loans, internet fraud and occupational fraud) obtained are included in the model by finding the arithmetic mean used. This is because it is easy to compute. However, with two or more variables, they appropriately make use of the arithmetic mean to arrive at the average.

\section{Control Variables}

To secure robustness of the model and for description bias, the model included the following variables to control bias of the model. The variables are long term capital and the number of years of operation of the financial institution. The long term capital is the percentage of shareholders' equity to the total long term capital of the financial institutions. It is made up of the equity finance provided by the shareholders of the company and long term debt finance by outsiders (Albanez, 2015). This is given by LTC= Shareholders Equity

Total long-Term Capital

The idea of including number of years of operations as control variable is that it can affect the number of customers a financial institution will have and the extent of fraud that would be experienced by the organization. A financial institution, which has been in operations for many years, is likely to have large customer base because of the trust and terrific correlation in the banking market over the newly established banks. Therefore, the probability of experiencing fraud is high than the new firms in the market due to pressure, inefficiencies, transformation of technological trends, etc.

\section{DATA PRESENTATION, ANALYSIS AND DISCUSSION Descriptive Analysis}

The descriptive analysis present and discuss the data obtained from structured questionnaire (primary data). The questionnaires are used to obtain the responses of the survey, the causes, deterrence, and the prevention of fraud associated with financial institutions. The questionnaire is made up of 35 questions which were divided into three sections. Section A consists of the profile of the Respondent (5). Sections two contains 15 questions given to the 
respondent on the causes of fraud in financial institutions. Finally, the third Section contains 15 questions concerning deterrence and the prevention of fraud in financial institutions in Ghana. A total of two hundred (200) questionnaires were distributed to the selected public and private financial institutions from which one hundred and fifty (150) were returned representing $87 \%$. The distribution was done through hand delivery, by email, and through personal collection.

\begin{tabular}{|l|l|l|l|}
\hline $\begin{array}{l}\text { Questionnaires } \\
\text { Outcome }\end{array}$ & Number of Questionnaires Issued Out & Number of Questions & $\begin{array}{l}\text { Percentages } \\
\text { of Responses }\end{array}$ \\
\hline $\begin{array}{l}\text { Set } \\
\text { Questionnaires }\end{array}$ & 200 & 35 & 100 \\
\hline $\begin{array}{l}\text { Filled and } \\
\text { Returned }\end{array}$ & 150 & 35 & 87 \\
\hline Unreturned & 50 & 5 & 13 \\
\hline
\end{tabular}

Accordingly, from the above table, majority of the financial institutions responded to the questions posed. A respond rate between 30 percent and 80 percent of the total sample size can be made to embody the opinion of the entire population (Cooper \& Schindler, 2008).

\section{a. Causes of Fraud in Financial Institutions in Ghana.}

Based on the questionnaires administered to the targeted respondents, Accountants, Auditors, and managers were asked to indicate the causes of fraud in financial Institutions based on the types of fraud mentioned: internal fraud, Stolen Checks, Fraudulent Loan, Forged Document, Electronic Fraud, and Accounting fraud.

Table 1. The causes of fraud on financial institutions in Ghana and the percentages at which it emerges

\begin{tabular}{|llll|}
\hline Causes of Fraud & $\begin{array}{l}\text { Percentage } \\
\text { S }\end{array}$ & Mean & $\begin{array}{l}\text { Standard } \\
\text { Deviation }\end{array}$ \\
\hline Poor Remuneration & 78 & $4.85(5)$ & .196 \\
Weaker Internal Control & 89 & $5.56(1)$ & .32 \\
Attitude to Defraud Organization & 73 & $4.55(7)$ & .193 \\
Nature and History of Account Holder & 70 & $4.5(8)$ & .241 \\
Poor Supervision & 77 & $4.65(6)$ & .115 \\
Inadequate Training and Fraud Policies & 87 & $5.43(2)$ & .193 \\
Falsified Documents & 85 & $5.25(3)$ & .067 \\
Dubious Relationship $\quad$ between & & & \\
Employees and Outsiders & 79 & $5.14(4)$ & .222 \\
\hline
\end{tabular}

From the table illustrated above, majority of the respondents agreed that weaker internal control is a strong arsenal that creates Fraud on financial Institutions in Ghana. It is followed by inadequate training and fraud policies with a mean (5.43) and 87 percent of it occurrence; falsified Documents with 
a mean (5.25) and 85 percent of its occurrence; and Dubious relationship between employees and outsiders (5.14) and Poor remuneration with mean of (4.85) according to the respondent perception on the causes of fraud to the financial Institutions.

Weaker internal controls in the financial institutions were strong causes of fraud internally. This occurs where managers or employees wield much power with no or less control, and ill crafted internal controls. Empirically from the data obtained, none of the financial institutions in Ghana has a fraud department. The internal audit department of the financial institutions is weak and unproductive because of their huge assignment of scrutinizing financial statements and material misstatement. Therefore, less attention has been given on detecting and fighting banking fraud. With this, employees takes advantage of it to steal, conceal payments, and at times misrepresent contracts. Also, it is an embodiment through which all types of fraud are mounted on the financial strength of the organizations.

Inadequate training and fraud policy has caused huge sums of money on most financial institutions in Ghana. When a financial institution fails to create, maintain fraud policies and carry out training for guiding employees, it becomes tedious to detect that one has committed a fraudulent act. Employees takes advantage of it by committing fraud since is often the first excuse perpetrators will use when questioned relating to fraud (Othman Aris et al., 2015). The next most important factor that caused fraud according to the respondent is falsified Documents.

This emerges through altering, changing, or modifying a document for the purpose of deceiving others. Due to respect, dubious relationship that exists between employees within or outsiders can be detrimental to the financial position of the financial company. Managers at times use their positions to connive with outsiders (account holders) to embezzle the funds of the banks. Finally, poor remuneration also caused fraud to financial institutions. The economy of Ghana has witnessed slow Gross Domestic Product in the past years and this unfavorable contingence has contributed to hardships on subordinates (Yiadom McWade et al., 2018). Things always increases at an increasing rate whereby the remuneration of subordinates stand still as well as pressure from relatives and friends. These grievances and financial needs made employees to resort to thievery as a means to survive.

\section{b. Deterrence and Prevention Methods of Fraud on Financial Institutions}

Fraudulent acts, asset misappropriation, stolen checks, employee's fraud, fraudulent loan, electronic fraud, accounting fraud, and forged Documents have become a major cost for many organizations especially financial institutions. Numerous fraud prevention and detection methods are now used to bring the direct and indirect cost of fraud to it bearest minimum. 
Therefore, respondents were also asked on the most effective deterrence and prevention method in fighting fraud which has been a terrific canker in most financial organizations.

Table 2. Deterrence and prevention of Fraud on Financial Institutions

\begin{tabular}{llll}
\hline Deterrence and Prevention Method & Percentages & Mean & $\begin{array}{l}\text { Standard } \\
\text { Deviation }\end{array}$ \\
Maintain Fraud Policy & 60 & $5.65(4)$ & .0121 \\
Good Remuneration & 55 & $5.81(2)$ & .072 \\
Employees Background Checks & 57 & $5.7(3)$ & .025 \\
Annual Auditing & 67 & $5.25(6)$ & .084 \\
Maintain Proper Book-keeping & 63 & $5.45(5)$ & .181 \\
Adequate Training & 71 & $5.51(4)$ & .191 \\
Bank Reconciliation & 77 & $5.12(7)$ & .176 \\
Password Protection & 50 & $5.85(1)$ & .096 \\
\hline
\end{tabular}

From the table above, it is obvious that password protection were perceived as the most effective detection and prevention fraud method with a mean $(x=5.85)$ and a percentage use of $50 \%$. It was followed by good remuneration with a mean $(x=5.81)$, employees background checks $(x=5.71)$, maintaining fraud policy $(\mathrm{x}=5.65)$, and maintaining book keeping with mean $(x=5.45)$. The least deterrence and prevention method to curb fraud is Bank Reconciliation. It is evident to note that organizational use of password protection was a least often utilized method, but it had the highest rate of bringing the incidence of fraud to the bearest minimum.

Therefore, financial institutions should install password on their computers in order to prevent costly fraud internally. By ensuring that employees are capable of gaining access into the user's computers security, the utilization of password can help them in preventing and detecting employee's fraud. It can be executed by needing a password before gaining entry to functions that fork from the excellent procedure. Additionally, password ought to be changed regularly. However, good salaries and conditions of services can halt fraudulent act happenings in the financial organizations. Employees are to be paid often well to push them from converting employer's monies to their own use in a bid to meet their social and personal needs. This temptation is even stronger on financial institutions workers who, on daily basis, have to deal with cash and near cash tool.

Meanwhile, it is very pivotal for every organization to check and screen employees and it is the first line of defense against fraud ( $\mathrm{Li}$ Bonsu et al., 2018). It is only in the few years that many organizations have come to value its importance. The pre-employment screening and background checking has been included in the Australian standard on fraud and corruption control. 
About $71 \%$ of all fraud cases reported are made by inside perpetrators (PriceWaterhouseCoopers survey, 2007).

Bank Reconciliation was perceived as the least deterrence and prevention method in fighting fraud on financial institutions. All accounts reconciliations and general ledger balances should have an independent review by person outside the duty areas such as Accountant, Auditors, investors, and analyst since most studies revealed that several acts are committed by organizations including managers, accountants, tellers, and management (Assenso-Okofo Ali et al., 2011).

\section{Statistical Measure of the Effects of Fraud on Financial Institutions (Banks)}

This section analyzes statistically the effects of banking fraud on a firm's financial performance using the cross-sectional regression model. The assumptions highlighting the regression model are tested and the results are displayed below.

\section{Descriptive Statistics of Data of Regression Model}

It summarizes the mean, standard deviations, and the maximum and minimum results of the variables obtained from the combination of the primary data and secondary data.

Table 3. Summary statistics

\begin{tabular}{lllccl}
\hline Variable & Observation & Mean & Std Dev. & Minimum & Maximum \\
\hline ROA & 10 & 3.58 & 4.61 & .24 & 14.63 \\
INTF & 10 & 4.60 & 0.90 & 2.73 & 5.56 \\
STCS & 10 & 3.36 & 0.82 & 2.51 & 5.2 \\
FRLS & 10 & 3.56 & 0.65 & 2.52 & 4.54 \\
FDOC & 10 & 3.38 & 0.65 & 2.12 & 4.61 \\
ELFD & 10 & 4.20 & 0.58 & 3.22 & 4.81 \\
ACCFD & 10 & 5.11 & 0.94 & 3.13 & 5.85 \\
LGT & 10 & 1.07 & 0.49 & .59 & 2.19 \\
NY & 10 & 37.7 & 28.02 & 8.0 & 100 \\
\hline
\end{tabular}

From the table above, it is obvious that an average of 3.58 is attained by financial institutions in Ghana on their financial performance (Return on Assets [ROA]). It comes with a range of 14.39 that stems from a minimum of 0.24 for the banking institutions on their total assets and a maximum of 14.63 on the other side. Internal fraud (INTF), with an average of 4.60 of the institutions, was impacted by fraud internally based on the respondent's perceptions. With this, a minimum of 2.73 and a maximum of 5.56 of financial institutions experienced internal fraud. On stolen checks (STCS), an average 
of 3.36 of institutions did bear stolen checks of which 2.51 was the minimum and 5.2 maximum of which financial institutions suffered from stolen check. Fraudulent Loans (FRLS) posited a mean of 3.56, Forged Documents (FDOC) with a mean of 3.38, electronic fraud (ELFD) with a mean of 4.20 , and Accounting Fraud (ACCFD) with a mean of 5.11 respectively. Moreover, the average number of years it took financial institutions to have a strong financial posture in the banking market is 37.7 years with a maximum and a minimum of 6 and 98 years respectively. For the long term capital ratio (LGT), it can be observed from the table that an average of 1.07 total equity capital to the long term capital is needed by the financial institutions to be retained in the banking market in Ghana.

Table 4. Correlation coefficient

\begin{tabular}{|c|c|c|c|c|c|c|c|c|c|}
\hline & ROA & INTF & STCS & FRLS & FDOC & ELEFD & ACCFD & LGT & NY \\
\hline ROA & $\begin{array}{l}1 \\
-\end{array}$ & & & & & & & & \\
\hline INTF & $\begin{array}{l}0.1474 * * \\
-\end{array}$ & 1 & & & & & & & \\
\hline STCS & $\begin{array}{l}0.3651 * * \\
-\end{array}$ & 0.4721 & 1 & & & & & & \\
\hline FRLS & $\begin{array}{l}0.2383 * * \\
-\end{array}$ & 0.1293 & 0.0368 & 1 & & & & & \\
\hline FDOC & $\begin{array}{l}0.2383 * * \\
-\end{array}$ & 0.5068 & 0.3007 & 0.2202 & 1 & & & & \\
\hline ELFD & $\begin{array}{l}0.2857 * * \\
-\end{array}$ & 0.6498 & 0.5440 & 0.3007 & 0.3436 & 1 & & & \\
\hline ACCFD & $0.4280 * *$ & 0.9094 & 0.3784 & 0.1563 & 0.4293 & 0.6249 & 1 & & \\
\hline LGT & 0.2378 & 0.2967 & 0.2183 & 0.3607 & 0.4301 & 0.0322 & 0.4589 & 1 & \\
\hline NY & 0.1262 & 0.1215 & 0.4129 & 0.3813 & 0.1286 & 0.5241 & 0.0883 & 0.1412 & 1 \\
\hline
\end{tabular}

The relationship between variables of the study was tested using correlation. Based on the findings from Table 4 on the correlation analysis, there is a negative relationship between financial performance (Return on Assets) and the fraud variables (that is internal fraud, stolen checks, fraudulent loans, forged documents, electronic fraud and accounting fraud). However, there is positive relationship between ROA and the number of years and Longterm capital of financial institutions.

Table 5. Results of regression model (1)

\begin{tabular}{|l|l|l|l|}
\hline Multiple R & R Square & Adj R-squared & Std. Error of Estimate \\
\hline 0.71 & 0.94 & 0.49 & 3.27 \\
\hline
\end{tabular}


Based on the findings from the above table, the independent variables showed 49 percent of the variation in ROA. Multiple R is the correlation coefficient which shows the relationship between the study variables. The finding from the table shows that there is a strong relationship between study variables as shown by 0.71 .

Table 6. Results of Regression model (2)

\begin{tabular}{lllll}
\hline Variables & Coef. & Std Err. & t-stat. & P value. \\
INTF & -15.77 & 4.59 & $-3.43^{* *}$ & 0.01 \\
STCS & -4.15 & 1.92 & $-2.16^{* *}$ & 0.02 \\
FRLS & -3.37 & 2.77 & $-3.13^{* *}$ & 0.07 \\
FDOC & -1.69 & 2.41 & $-1.71^{* *}$ & 0.03 \\
ELFD & -2.01 & 4.63 & $-1.81^{* *}$ & 0.01 \\
ACCFD & -14.41 & 4.24 & $-3.40^{* *}$ & 0.02 \\
LGT & 2.31 & 3.61 & $2.47^{* *}$ & 0.06 \\
NY & 0.045 & 0.78 & 1.84 & 0.08 \\
\hline
\end{tabular}

Note: $* *$ indicates significance level of $10 \%$

As shown in the Table 6, it is known that there is a significant negative relationship existing between Internal Fraud, Stolen Checks, Fraudulent Loans, Forged Documents, Electronic Fraud, Accounting Fraud, and Return on Assets. It can be seen that a unit change in Internal Fraud would lead to a decrease in a firm's financial performance by a margin of 15.77. On the other hand, a unit change in Stolen Checks, Fraudulent Loans, Forged Documents, Electronic Fraud, and Accounting Fraud would lead to a decrease on Returns on Assets by 4.15, 3.37, 1.78, 1.69, 2.01, and 14.41 respectively. Meanwhile, long term investment of financial institutions would lead to 2.31 increments in Return on Assets (ROA) of Ghanaian financial institutions. Therefore, based on the analysis, internal fraud, stolen checks, fraudulent loans, forged documents, electronic fraud, accounting fraud, and long term capital have a significant impact on the financial performance of financial institutions.

Table 7. Analysis of the Regression model (3)

ANOVA

\begin{tabular}{lccccc}
\hline & $\boldsymbol{d} \boldsymbol{f}$ & $\boldsymbol{S S}$ & $\boldsymbol{M S}$ & $\boldsymbol{F}$ & Prob $>\boldsymbol{F}$ \\
\hline \hline Model & 8 & 180.739 & 9.9087 & 2.10 & 0.49 \\
Residuals & 1 & 10.739 & 10.50 & & \\
Total & 9 & 191.478 & & & \\
\hline \hline
\end{tabular}


On the Analysis on Variance statistics as shown on the table above, the independent variables gives a good fit at the significance $\mathrm{F}$ value since it is less than 0.5 . Therefore, the model was statistically significant.

\section{CONCLUSION}

The study investigated the causes, effects, deterrence, and prevention of corporate fraud on financial institutions in Ghana. The results revealed that weaker internal control, inadequate training and fraud policies, failed document, dubious relationship between employees and outsiders, and poor remuneration were the main causes of fraud in financial institutions in Ghana. On the side of finding the effects of fraud on firm's financial performance, a cross sectional model was used. The results revealed that fraud has a significant negative effects on financial performance i.e. Return on Assets of financial institutions in Ghana. Therefore, accountants, auditors, analysts, managers, and all stakeholders should be careful with the emergence of fraud since it is immune. However, fool proof deterrence and prevention methods are recommended based on the findings from the study. It was revealed that password protection, good remuneration, employee's background checks, adequate training, and maintaining proper book-keeping are the most methods in curbing fraudulent acts hitting the financial organizations.

\section{PRACTICAL IMPLICATION AND RECOMMENDATIONS}

Corporate fraud has gained special attention in every economy in the world since it is immune. Therefore, employees and all stakeholders should be educated on the emergence of fraud and its consequences on organizations and on a country's economy. The study will help accountants and auditors on the appropriate detection and prevention methods in curbing future fraud as discussed in the study, especially organizational use of password protection on computers, employees background checks, and prompt payment of good remunerations to employees.

In this study, we therefore recommend that fraud polices has to be instituted and executed rigorously in guiding employees. Employees should comply with policies when it is clearly stated with detailed methods followed. Finally, a special research and development unit must be instituted to research into this area and mount out the new proof methods of fighting against this menace and canker on the burden of every organizations. Future studies should explore more on the financial institutions fraud in regards to others in the banking industry.

\section{References:}

1. ACFE US (2017). ACFE Occupational Fraud Report to Nations Survey. 
2. Albrecht, W.S. \& Albrecht, C.C. (2002). "Root out financial deception: detect and eliminate fraud or suffer the consequences", Journal of Accountancy, April, pp. 30-34.

3. Assenso-Okofo, O. et al. (2011). "The Development of Accounting and Reporting in Ghana." The International Journal of Accounting 46(4): 459-480.

4. Bank of Ghana (2016). Intelligence Report of fraud on Financial Institutions, Ghana.

5. Bhasin, M. (2015). AN EMPIRICAL STUDY OF FRAUDS IN THE BANKS.

6. Carl, N. (2017). "Ethnicity and electoral fraud in Britain." Electoral Studies 50: 128-136.

7. Chen, Y. et al. (2011). "Corporate fraud and bank loans: Evidence from china." China Journal of Accounting Research 4(3): 155-165.

8. Cooper, C.R., \& Schindler, P.S. (2008). Business research methods (10 Ed.). Boston: McGrawHill.

9. Cressey, D. R. (1971). Other peoples' money: A study in the social psychology of embezzlement. Glencoe: Free Press: accessed on 9 January 2015.

10. Daniela, P., \& Attila, T. (2013). Internal audit versus internal control and coaching. Procedia Economics and Finance, 6, 694-702

11. Dixit, A. \& Nalebuff, B. (1960). Game Theory Sweet \& Maxwell Ltd, London.

12. de Sá, A. G. C. et al. (2018). "A customized classification algorithm for credit card fraud detection." Engineering Applications of Artificial Intelligence 72: 21-29.

13. Gill, M. \& Goldstraw-White, J.E. (2010). Theft and fraud by employees. In: Brookman, F., Maguire, M., Pierpoint, H., Bennett, T.H. (Eds.), Handbook of Crime. Willan, Cullompton.

14. Isaac akomea-frimpong Charles Andoh Eric Dei Ofosu-Hene (2016)."Causes, effects and deterrence of insurance fraud: evidence from Ghana", Journal of Financial Crime, Vol. 23.

15. Klement, A. et al. (2018). "Consumer Fraud, Misrepresentation and Reliance." International Review of Law and Economics 54: 95-105.

16. KPMG Africa (2013). KPMG Fraud Barometer, Bribery and Corruption Survey.

17. KPMG Fraud, Bribery and Corruption Survey (2012). Retrieved from: http://www.kpmg.com/au/en/issuesandinsights/articlespublications/fra udsurvey/pages/fraud-bribery-corruption-survey-2012.aspx

18. KPMG Malaysia (2013). KPMG Malaysia Fraud, Bribery and Corruption Survey. 
19. Lang, M. \& Wambach, A. (2013). "The fog of fraud - Mitigating fraud by strategic ambiguity." Games and Economic Behavior 81: 255-275.

20. Li, K., et al. (2018). "Accountants Perception on Effectiveness of Corporate Fraud Detection and Prevention Methods in Ghana." International Journal of Accounting and Financial Reporting 8(3): 78.

21. Lisic, L. L. et al. (2015). "Accounting fraud, auditing, and the role of government sanctions in China." Journal of Business Research 68(6): 1186-1195.

22. Othman, R. et al. (2015). "Fraud Detection and Prevention Methods in the Malaysian Public Sector: Accountants' and Internal Auditors' Perceptions." Procedia Economics and Finance 28: 59-67.

23. Purnamasari, P. \& Amaliah, I. (2015). "Fraud Prevention: Relevance to Religiosity and Spirituality in the Workplace." Procedia - Social and Behavioral Sciences 211: 827-835.

24. Schuchter, A. \& Levi, M. (2015). "Beyond the fraud triangle: Swiss and Austrian elite fraudsters." Accounting Forum 39(3): 176-187.

25. Xu, Y. et al. (2017). "Board age and corporate financial fraud: An interactionist view." Long Range Planning.

26. Yiadom, M. Y. A. B. et al. (2018). "Public Health Rationale for Investments in Emergency Medicine in Developing Countries - Ghana as a Case Study." The Journal of Emergency Medicine.

27. Yusuf, O.T. (2010). Brokers and the control of post contractual opportunism in the Nigerian insurance market, Journal of Financial Crime, 17 (2), $223-239$.

28. Yusuf, O.T. (2011). Brokers' incentives and conflicts of interest in the control of opportunism", The Journal of Risk Finance, 12 (3), 168 - 18

29. Zunzunegui, M. V. et al. (2017). "Financial fraud and health: the case of Spain." Gaceta Sanitaria 31(4): 313-319. 